\title{
Chemoselective Reduction of Nitroarenes with Hydrazine over a Highly Active Alumina-Supported Cobalt Nanocatalyst
}

\author{
Jalal Albadi, ${ }^{1, \star}$ Heshmat Allah Samimi $^{1}$ and Mehdi Jalali ${ }^{2}$ \\ ${ }^{1}$ Department of Chemistry, Faculty of Science, Shahrekord University, Shahrekord, Iran \\ ${ }^{2}$ National Petrochemical Company, Petrochemical Research and Technology Company, Tehran, Irana \\ *Corresponding author: E-mail: chemalbadi@gmail.com:albadi@sci.sku.ac.ir: \\ Tel./Fax.: +9838132324419
}

Received: 06-09-2018

\begin{abstract}
A green and efficient procedure is reported for the chemoselective reduction of nitroarenes catalyzed by a highly active alumina-supported cobalt nanocatalyst in the presence of hydrazine hydrate. The nanocatalyst can be applied under mild reflux conditions for the synthesis of arlyamines in high yields. Moreover, the catalyst can be easily recovered by simple filtration and reused several times without obvious loss in its catalytic activity.
\end{abstract}

Keywords: Cobalt catalysis; nanocatalyst; chemoselective reduction; nitroarenes; arylamines

\section{Introduction}

Arylamines are industrially important organic intermediates and attractive compounds for the chemical synthesis due to their wide utility in fine chemicals dyes and polymers. ${ }^{1}$ These compounds are important components in many biologically active natural products, medicinally compounds, materials with useful electrical and mechanical properties. ${ }^{2-3}$ Arylamines were synthesized by various processes such as reduction of corresponding nitroarenes in the presence of metallic catalysts. Thus exploring new procedures or catalysts for the chemoselective reduction of nitroarenes have been attracted considerable attention.

In the previous studies, a variety of metallic catalysts and methods were reported for the synthesis of arylamines. ${ }^{4-16}$ However, some of these catalysts possess the lack of chemoselectivity, adaptability to nitro-containing substrates and recyclability. Moreover, some of these methods incude the use of toxic solvents, hard work-up, low selectivity and harsh reaction conditions. Therefore, the catalytic activity need to be further improved, and introduction of alternative methods for the chemoselective reduction of nitroarenes to their corresponding arylamines in terms of potential simplicity, high activity and environmental process is still in demand.
In recent years, supported cobalt catalysts have been attracted significant attention on the organic synthesis reactions and proved to be useful for the reduction of nitroarenes. Various supported cobalt catalysts were prepared and their catalytic activity studied on the reduction of nitroarenes. ${ }^{17-23}$ It is confirmed that supported cobalt catalysts had good activity and selectivity for the chemoselective reduction of nitro compounds. However, to the best of our knowledge, there is no report on the reduction of nitroarenes in the presence of alumina supported cobalt nanoparticles. Moreover, recently, the use of supported metallic nanoparticles as catalysts have gained a great attention. These compounds show an important role in nanoscience and nanotechnology. It is proved that the supported nanoparticles have higher stability. Separation and recycling properties also increase. Therefore, due to these properties, the practical applications of supported metallic nanoparticles as catalysts on the organic synthesis reactions have increased. ${ }^{24-28}$

Recently, we have reported the preparation and characterization of cobalt nanoparticles supported on $\mathrm{Al}_{2} \mathrm{O}_{3}$ as support $\left(\mathrm{Co} / \mathrm{Al}_{2} \mathrm{O}_{3}\right.$ nanocatalyst), as well as its catalytic activity on the various organic reactions. ${ }^{29-30} \mathrm{Co} / \mathrm{Al}_{2} \mathrm{O}_{3}$ nanocatalyst is safe, stable, easy to handle, environmentally benign and its preparation is simple. It was observed that $\mathrm{Co} / \mathrm{Al}_{2} \mathrm{O}_{3}$ nanocatalyst had high activity, selectivity 
and recyclability in the aerobic oxidation of alcohols. In continuation of our studies on the catalytic activity of different nanocatalysts on organic reactions, ${ }^{31-36}$ herein, we report an efficient and green procedure for the chemoselective reduction of nitroarene compounds catalyzed by cobalt nanoparticles supported on $\mathrm{Al}_{2} \mathrm{O}_{3}$ support $(\mathrm{Co} /$ $\mathrm{Al}_{2} \mathrm{O}_{3}$ nanocatalyst) in ethanol under reflux conditions (Scheme 1).<smiles>[R]c1cccc([N+](=O)[O-])c1</smiles>

$$
\frac{\mathrm{Co} / \mathrm{Al}_{2} \mathrm{O}_{3} \text { nanocatalyst }}{\mathrm{N}_{2} \mathrm{H}_{4} \cdot \mathrm{H}_{2} \mathrm{O}, \text { EtOH, reflux }}
$$

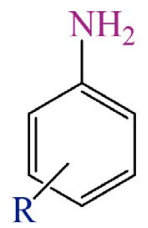

\section{R:Ph, Me, OMe, $\mathrm{OH}, \mathrm{N}(\mathrm{Me})_{2}, \mathrm{Cl}, \mathrm{Br}, \mathrm{CHO}, \mathrm{H}$}

Scheme 1. Chemoselective reduction of nitroarenes catalyzed by $\mathrm{Co} / \mathrm{Al}_{2} \mathrm{O}_{3}$ nanocatalyst.

\section{Results and Discussion}

Results confirmed that cobalt nanoparticles supported on $\mathrm{Al}_{2} \mathrm{O}_{3}$ support $\left(\mathrm{Co} / \mathrm{Al}_{2} \mathrm{O}_{3}\right.$ nanocatalyst $)$ can be considered as an simple, efficient, green and recyclable nanocatalyst for the synthesis of various functionalized arylamines. In this process, conversion of different substrates with high selectivity of corresponding arylamines have been achieved and $\mathrm{N}_{2}$ was only obtained as the by-product. Therefore, this process can present a highly efficient and clean procedure for the reduction of nitroarenes and synthesis of functionalized arylamines.

$\mathrm{Co} / \mathrm{Al}_{2} \mathrm{O}_{3}$ nanocatalyst was prepared by a co-precipitation method. Scanning electron microscopy (SEM), energy dispersive spectroscopy (EDS), BET surface area, $\mathrm{X}$-ray diffraction (XRD) and TEM analysis were used to characterize the catalyst. ${ }^{25}$

To optimize the reaction conditions, reduction of 4-chloronitrobenzene in the presence of hydrazine hidrate, was chosen as a model reaction and its performance was studied under a variety of conditions. The effect of various factors such as solvent, catalyst amount and temperature were investigated. The reaction was studied in the presence of different amounts of the nanocatalyst, and found that the catalyst amount confirmed different activities in this reaction. Amongst various amount of the catalyst studied, it was found that in the presence of the $\mathrm{Co} /$ $\mathrm{Al}_{2} \mathrm{O}_{3}$ nanocatalyst $(0.1 \mathrm{~g})$, 4-chloro-aniline was obtained in highest yield and lower reaction times. While the nanocatalyst amount was decreased, the corresponding product obtained in the lower yields. Moreover, overloading had no significant effect on the yield and time of the reaction (Table 1).
Table 1. Effect of the catalyst amount on the reduction of 4-chloronitrobenzene. ${ }^{\mathrm{a}}$

\begin{tabular}{cccc}
\hline Entry & Catalyst amounts $(\mathbf{g})$ & Time $(\mathbf{h})$ & Yield (\%) \\
\hline 1 & 0.03 & 10 & 35 \\
2 & 0.05 & 8.5 & 55 \\
3 & 0.07 & 5.2 & 70 \\
4 & 0.1 & 3 & 94 \\
\hline
\end{tabular}

a Reaction conditions: 4-chloro-nitrobenzene ( $1 \mathrm{mmol}$ ), $\mathrm{N}_{2} \mathrm{H}_{4} \cdot \mathrm{H}_{2} \mathrm{O}$

$(3 \mathrm{mmol})$, in ethanol at reflux conditions. ${ }^{\mathrm{b}}$ Isolated pure products.

The effect of various solvents in this reaction was also investigated (Table 2). It was confirmed that the reaction in organic solvents such as $\mathrm{CH}_{3} \mathrm{CN}$ and toluene is significantly low, whereas the reduction proceeded efficiently in ethanol under reflux condition. The rate of the reaction was slower in water and yield of corresponding product was decreased. Other solvents such as methanol and ethyl acetate were less effective for this reaction. Therefore, ethanol was selected as the solvent for the reduction reaction (Table 2). Moreover, the effect of various amounts of hydrazine hidrate were investigated. The best results were obtained in the presence of $3 \mathrm{mmol}$ of hydrazine hidrate (Table 2).

Table 2. Optimization study of the hydrazine hidrate and different solvents on the reduction of 4-chloronitrobenzene. ${ }^{\text {a }}$

\begin{tabular}{cccrc}
\hline Entry & Conditions & $\begin{array}{c}\mathbf{N}_{\mathbf{2}} \mathbf{H}_{\mathbf{4}} \cdot \mathbf{H}_{\mathbf{2}} \mathbf{O} \\
(\mathbf{m m o l})\end{array}$ & $\begin{array}{c}\text { Time } \\
\mathbf{( h )}\end{array}$ & $\begin{array}{c}\text { Yield } \\
\mathbf{( \% )}\end{array}$ \\
\hline 1 & $\mathrm{H}_{2} \mathrm{O} /$ r.t. & 3 & 18 & - \\
2 & $\mathrm{H}_{2} \mathrm{O} /$ reflux & 3 & 8 & 70 \\
3 & EtOH/ r.t. & 3 & 18 & Trace \\
4 & EtOH/reflux & 1.5 & 7 & 45 \\
5 & EtOH/reflux & 2 & 5 & 76 \\
6 & EtOH/reflux & 3 & 3 & 94 \\
7 & MeOH/reflux & 3 & 7 & 50 \\
8 & $\mathrm{CH}$ CN/ reflux & 3 & 8 & 40 \\
9 & Ethyl acetate/ reflux & 3 & 12 & 40 \\
10 & Toluene/reflux & 3 & 12 & 20 \\
\hline
\end{tabular}

a Reaction conditions: 4-chloronitrobenzene ( $1 \mathrm{mmol}), 0.1 \mathrm{~g}$ catalyst. ${ }^{b}$ Isolated pure products.

To study the scope of this procedure, the reduction reactions of various nitroarene compounds were investigated. A wide range of substituted aromatic nitro compounds were reduced to the corresponding aryl amine derivatives in the presence of $\mathrm{Co} / \mathrm{Al}_{2} \mathrm{O}_{3}$ nanocatalyst (Table 3).

The obtained results represented that various substituted nitroaromatics including electron-withdrawing groups and electron-donating groups were reduced under the optimized reaction conditions and corresponding arylamines were obtained in high yields. Halogeno-substi- 
Table 3. Chemoselective reduction of nitroarenes catalyzed by $\mathrm{Co} / \mathrm{Al}_{2} \mathrm{O}_{3}$ nanocatalyst. ${ }^{\mathrm{a}}$

\begin{tabular}{|c|c|c|c|c|}
\hline Entry & Substrate & Product $^{b}$ & Time (h) & Yield (\%) ${ }^{c}$ \\
\hline 1 & & & 3 & 91 \\
\hline 2 & & & 3 & 94 \\
\hline 3 & & & 4 & 91 \\
\hline 4 & & & 3 & 93 \\
\hline 5 & & & 3 & 94 \\
\hline 6 & & & 3 & 93 \\
\hline 7 & & & 2 & 92 \\
\hline 8 & & & 3 & 91 \\
\hline 9 & & & 4.5 & 89 \\
\hline 10 & & & 5 & 88 \\
\hline 11 & & & 4.5 & 90 \\
\hline 12 & & & 3 & 90 \\
\hline 13 & & & 3 & 91 \\
\hline 14 & & & 3 & 92 \\
\hline 15 & & & 3 & 89 \\
\hline
\end{tabular}

${ }^{a}$ Reaction conditions: nitro compound $(1 \mathrm{mmol}), \mathrm{N}_{2} \mathrm{H}_{4} \cdot \mathrm{H}_{2} \mathrm{O}(3 \mathrm{mmol})$ and $\mathrm{Co} / \mathrm{Al}_{2} \mathrm{O}_{3}$ nanocatalyst $(0.1 \mathrm{~g})$ in ethanol at reflux conditions. ${ }^{b}$ Products were characterized by comparison of their spectroscopic data and melting points with those reported in the literature. ${ }^{5,9,11,13,35 \mathrm{c}}$ Isolated pure products. 
tuted nitroarenes were reduced to the corresponding products without any dehalogenation in high yields (Table 3, entries 2-4). Moreover, the reducible functional groups on aromatic rings like $\mathrm{OH}$ and aldehyde group remained completely unchanged under the reaction conditions (Table 3 , entries 8-10). Especially, the reduction reaction of nitroaniline also occurred efficiently to give the corresponding phenyl diamine in high yield (Table 3 , entry 11 ). The reduction of biphenyl nitrocompounds also gave the excellent yields of the corresponding products with good selectivity under the reaction conditions (Table 3, entry 13-15).

Various methoxy-substituted nitro compounds such as 3,4,5-trimethoxynitrobenzene gave the corresponding methoxy anilines in high yields (Table 3, entry 6,7). The chemoselective reduction of the nitroarene compounds in the presence of an aldehyde group was also studied by reduction of nitrobenzaldehydes (Table 3 entry 9,10 ). It was found that only $\mathrm{NO}_{2}$ group on aromatic ring was reduced and $\mathrm{CHO}$ group remained intact. Analysis of reaction products confirmed that corresponding aminobenzaldehydes were obtained in excellent yields with no by-product detected.

Generally, our procedure introduces the clean and efficient method for the chemoselective reduction of nitoarenes into aryl amines in the presence of $\mathrm{Co} / \mathrm{Al}_{2} \mathrm{O}_{3}$ nanocatalyst. In these processes, no intermediate products were found in the reaction mixtures, and the corresponding products were obtained in good to high yields. Workup procedure is simple and all products were isolated with simple filtration and evaporation of the solvent. Therefore, this method introduced $\mathrm{Co} / \mathrm{Al}_{2} \mathrm{O}_{3}$ nanocatalyst as a simple and promising catalyst for the chemoselective reduction of nitroarene compounds.

Moreover, the recyclability of the catalyst was also studied using 4-chloronitrobenzene as starting material, and reacted under optimized reaction conditions (Table 4). After the completion of the reaction, the catalyst was washed with hot ethanol, dried, and stored for another run. This process was repeated for five times, and no considerable decrease in the catalytic activity was observed.

Table 4. Recyclability study of $\mathrm{Co} / \mathrm{Al}_{2} \mathrm{O}_{3}$ nanocatalyst in reduction of 4-chloronitrobenzene. ${ }^{\mathrm{a}}$

\begin{tabular}{lrrccc}
\hline Run & 1 & 2 & 3 & 4 & 5 \\
Time (h) & 3 & 3 & 3.3 & 4 & 4.2 \\
Yield (\%) a $^{\text {a }}$ & 94 & 94 & 93 & 91 & 90 \\
\hline
\end{tabular}

${ }^{\mathrm{a}}$ Ioslated pure products.

\section{Experimental}

Chemicals were purchased from Aldrich and Merck chemical companies. Products were characterized by comparison of their spectroscopic data (NMR and IR) and physical properties with those reported in the literature.
The NMR spectra were recorded on a Bruker Avance 400 MHz. IR spectra were recorded on a Perkin Elmer 781 Spectrophotometer. Obtained yields refer to the isolated pure products. $\mathrm{Co} / \mathrm{Al}_{2} \mathrm{O}_{3}$ nanocatalyst was prepared according to the our previously reported method. ${ }^{29}$

\section{1. General Procedure}

Nitro compounds $(1 \mathrm{mmol})$, hydrazine hydrate $(3$ $\mathrm{mmol})$ and $\mathrm{Co} / \mathrm{Al}_{2} \mathrm{O}_{3}$ nanocatalyst $(0.1 \mathrm{~g})$ were added to round-bottom flask containing $10 \mathrm{~mL}$ of ethanol. The mixture was stirred under reflux condition for the appropriate reaction time (Table 3 ). The progress of the reaction was monitored by TLC ( $n$-hexane: EtOAc, 4:1). After reaction completion, the catalyst was filtered, and washed with hot ethanol. Evaporation of the solvent was followed by column chromatography on the silica gel which afforded the pure products in high yields.

\section{Conclusions}

We have reported an efficient and clean procedure for the chemoselective reduction of various nitroarenes catalyzed by Co-based nanoparticles $\left(\mathrm{Co} / \mathrm{Al}_{2} \mathrm{O}_{3}\right.$ nanocatalyst) in the presence of hydrazine in ethanol, as solvent. The catalyst could be easily separated, and reused at least 5 times without notable drop in its catalytic activity. Moreover, high yields, easy work-up and clean reaction procedure make the present method a useful and important reaction for the reduction of nitroamines. Studies on other functions of this catalyst are underway in our laboratory.

\section{Acknowledgement}

We are thankful to research council of Shahrekord University for the support of this research.

\section{References}

1. C. Desmarets, R. Schneider, Y. J. Fort, J. Org. Chem. 2002, 67, 3029-3036. DOI:10.1021/jo016352l

2. A. M. Tafesh, J. Weijuny, Chem. Rev. 1996, 96, 2035-2052. DOI: $10.1021 / \mathrm{cr} 950083 \mathrm{f}$

3. T. Ohno, K. Moriwaki, T. Miyata, J. Org. Chem. 2001, 66, 3397-3401. DOI:10.1021/jo001100q

4. Y. J, Jang, S. Kim, S. W. Jun, B. H. Kim, S. Hwang, I. K. Song, B. M. Kim, T. Hyeon, Chem. Commun. 2011, 47, 3601-3603. DOI:10.1039/c0cc04816j

5. V. Pandarus, R. Ciriminna, F. Béland, M. Pagliaro, Adv. Synth. Catal. 2011, 353, 1306-1316. DOI:10.1002/adsc.201000945

6. S. Zhao, H. Liang, Y. Zhou, Catal. Commun. 2007, 8, 13051309. DOI:10.1016/j.catcom.2006.11.033 
7. S. S. Kotha, N. Sharma, G. Sekar, Tetrahedron Lett. 2016, 57, 1410-1413. DOI:10.1016/j.tetlet.2016.01.111

8. A. K. Shil, D. Sharma, N. R. Guha, P. Das, Tetrahedron Lett, 2012, 53, 4858-4861. DOI:10.1016/j.tetlet.2012.06.132

9. P. F. Luo, K. L. Xu, R. Zhang, L. Huang, J. Wang, W. H. Xing, J. Huang, Catal. Sci. Technol. 2012, 2, 301-304. DOI:10.1039/C1CY00358E

10. N. R. Guha, D. Bhattacherjee, P. Das, Tetrahedron Lett. 2014, 55, 2912-2916. DOI:10.1016/j.tetlet.2014.03.047

11. S. Park, I. S. Lee, J. Park, Org. Biomol. Chem. 2013, 11, 395399. DOI:10.1039/C2OB27025K

12. X-U. Chen, B-R. Ai, Y. Dong, X-M. Zhang, J-Y. Wang, Tetrahedron Lett. 2017, 58, 3646-3649. DOI:10.1016/j.tetlet.2017.08.009

13. U. Sharma, N. Kumar, P. K. Verma, V. Kumar, B. Singh, Green. Chem. 2012, 14, 2289-2293. DOI:10.1039/c2gc35452g

14. M. O. Sydnes, M. Isobe, Tetrahedron Lett. 2008, 49, 11991202. DOI:10.1016/j.tetlet.2007.12.030

15. S. Wei, Z. Dong, Z. Ma, J. Sun, J. Ma, Catal. Commun. 2013, 30, 40-44. DOI:10.1016/j.catcom.2012.10.024

16. Y. Yamane, X. Liu, A. Hamasaki, T. Ishida, M. Haruta, T. Yokoyama, M. Tokunaga, Org. Lett. 2009, 11, 5162-5165. DOI:10.1021/ol902061j

17. K. N. Rao, B. M. Reddy, S.-E. Park, Catal. Commun. 2009, 11, 142-145. DOI:10.1016/j.catcom.2009.09.013

18. X. Cui, K. Liang, M. Tian, Y. Zhu, J. Ma, Z.J. Dong, Colloid Interface Sci. 2017, 501, 231-240.

DOI:10.1016/j.jcis.2017.04.053

19. P. Zhou, Z. Zhang, L. Jiang, C. Yu, K. Lv, J. Sun, S. Wang, Appl. Catal. B. Environ. 2017, 210, 522-532.

DOI:10.1016/j.apcatb.2017.04.026

20. C. Nethravathi, J. Prabhu, S. Lakshmipriya, M. Rajamathi, ACS. Omega. 2017, 2, 5891-5897.

DOI:10.1021/acsomega.7b00848

21. S. K. Mohapatra, S. U. Sonavane, R. V. Jayaram, P. Selvam, Tetrahedron Letters. 2002, 43, 8527-8529.

DOI:10.1016/S0040-4039(02)02080-4
22. U. Sharma, P. Kumar, N. Kumar, V. Kumar, B. Singh, $A d v$. Synth. Catal. 2010, 352, 1834-1840.

DOI:10.1002/adsc.201000191

23. F. A. Westerhaus, R. V. Jagadeesh, G. WienhÖfer, M.-M.; Pohl, J. Radnik, A.-E. Surkus, J. Rabeah, K. Junge, H. Junge, M. Nielsen, A. BrÜckner, M. Beller, Nat. Chem. 2013, 5, 537543. DOI:10.1038/nchem.1645

24. C. Jiang, Z. Shang, X. Liang, ACS Catal. 2015, 5, 4814-4818. DOI:10.1021/acscatal.5b00969

25. H. J. Freund, Surf. Sci. 2002, 500, 271-299. DOI:10.1016/S0039-6028(01)01543-6

26. S. M. H. Nasrollahi, M.A. Ghasemzadeh, M. R. Zolfaghari, Acta. Chim. Slov. 2018, 65, 199-207. DOI:10.17344/acsi.2017.3820

27. K. P. Boroujeni, S. Hadizadeh, S. Hassani, A. Fadavi, M. Shahrokh, Acta. Chim. Slov. 2017, 64, 692-700. DOI:10.17344/acsi.2017.3437

28. G. M. Ziarani, E. Tavaf, V. F. Vavsari, A. Badiei, Acta. Chim. Slov. 2017, 64, 701-706. DOI:10.17344/acsi.2016.3111

29. J. Albadi, A. Alihosseinzadeh, M. Jalali, M. Shahrezaei, A. Mansournezhad, Mol. Catal. 2017, 440, 133-139. DOI:10.1016/j.mcat.2017.07.020

30. J. Albadi, M. Jalali, A. R. Momeni, Res. Chem. Intermed. 2016, 42, 5739-5752. DOI:10.1007/s11164-015-2400-z

31. J. Albadi, A. Alihoseinzadeh, A. Mansournezhad, Acta. Chim. Slov. 2015, 62, 617-624. DOI:10.17344/acsi.2014.1211

32. J. Albadi, J. Abbasi Shiran, A. Mansournezhad, Acta. Chim. Slov. 2014, 61, 900-903.

33. J. Albadi, A. Mansournezhad, T. Sadeghi, Res. Chem. Intermed. 2015, 41, 8317-8326. DOI:10.1007/s11164-014-1894-0

34. J. Albadi, A. Alihoseinzadeh, A. Razeghi, Catal. Commun. 2014, 49, 1-5. DOI:10.1016/j.catcom.2014.01.030

35. J. Albadi, J. Abbasi Shiran, A. Mansournezhad, J. Chem. Sci. 2014, 126, 147-150.

DOI:10.1007/s12039-013-0537-0

36. J. Albadi, A. Mansournezhad, Chin. J. Chem. 2014, 32, 396398. DOI:10.1002/cjoc. 201400138

\section{Povzetek}

Avtorji v prispevku poročajo o učinkovitem in zelenem postopku kemoselektivne redukcije nitroarenov, ki jo katalizira visoko aktivni kobaltov nanokatalizator, nanešen na aluminijev oksid, v prisotnosti hidrazin hidrata. Nanokatalizator so uporabili pri milih pogojih refluksa in pri tem sintetizirali vrsto arilaminov z visokimi izkoristki. Ob tem je možno katalizator enostavno regenerirati s filtracijo in ponovno večkrat uporabiti, brez znatne izgube katalitske aktivnosti.

Except when otherwise noted, articles in this journal are published under the terms and conditions of the Creative Commons Attribution 4.0 International License 